\title{
Lytic polysaccharide monooxygenase of soil actinomycete with potential use for lignocellulose biodegradation
}

\author{
Esti Utarti ${ }^{1,2}$, Antonius Suwanto ${ }^{3}$, Maggy Thenawidjaja Suhartono ${ }^{4}$ and Anja Meryandini, ${ }^{3,5 *}$
}

${ }^{1}$ Microbiology Study Program, Department of Biology, Faculty of Mathematics and Natural Sciences, IPB University (Bogor Agricultural University), Agatis Street, IPB Dramaga Campus, Bogor 16680, Indonesia. ${ }^{2}$ Department of Biology, Faculty of Mathematics and Natural Sciences, Jember University, Kalimantan Street,

Tegalboto Campus, Jember 68121, Indonesia.

${ }^{3}$ Department of Biology, Faculty of Mathematics and Natural Sciences, IPB University (Bogor Agricultural University), Agatis Street, IPB Dramaga Campus, Bogor 16680, Indonesia.

${ }^{4}$ Department of Food Science and Technology, Faculty of Agricultural Technology, IPB University (Bogor

Agricultural University), Lingkar Akademik Street, IPB Dramaga Campus, Bogor 16680, Indonesia.

${ }^{5}$ Research Centre for Bioresources and Biotechnology, IPB University (Bogor Agricultural University), IPB

Dramaga Campus, Bogor 16680, Indonesia.

Email: ameryandini@apps.ipb.ac.id

Received 1 June 2020; Received in revised form 20 July 2020; Accepted 18 October 2020

\begin{abstract}
Aims: Lytic polysaccharide monooxygenase (LPMO) is an enzyme capable of cleaving glycoside bonds of recalcitrant polysaccharides through an oxidative mechanism. LPMO activity, in synergy with hydrolytic enzymes, increases the production of monomer sugars from the biodegradation of lignocellulose. This study was aimed at evaluating actinomycete S2 strain LPMO activity based on the release of xylose as one of reducing sugar and hydrogen peroxide $\left(\mathrm{H}_{2} \mathrm{O}_{2}\right)$ in the course of lignocellulosic biodegradation.

Methodology and results: The oxidation activity of LPMO from actinomycete S2 strain was measured by using the substrate of Avicel supplemented with ascorbic acid and copper ions $\left(\mathrm{Cu}^{2+}\right)$ to identify its effect on the release of xylose as one of reducing sugar. The optimum incubation time for the LPMO production was also conducted. Further, $\mathrm{H}_{2} \mathrm{O}_{2}$ quantitative analysis was performed as by-product of LPMO activity and 16S rRNA gene sequence of actinomycete S2 strain were subsequently determined. We found that supplementation of $1 \mathrm{mM}$ ascorbic acid and $0.2 \mathrm{mM} \mathrm{Cu}^{2+}$ increased xylose as one of reducing sugar production by up to 5 -fold from 255.03 to $1290 \mu \mathrm{g} / \mathrm{mL}$ after an optimal incubation period of 6 days. Based on $\mathrm{H}_{2} \mathrm{O}_{2}$ production, the LPMO activity of actinomycete S2 strain was $0.019 \pm 0.001 \mathrm{U} / \mathrm{mL}$. There is likelihood that LPMO activity derived from actinomycete S2 strain has a synergistic effect with the activity of other lignocellulose-degrading enzymes. This actinomycete showed 99\% similarity to the 16S rRNA gene sequence of Streptomyces avermitilis strain EAAG80.

Conclusion, significance, and impact of study: LPMO enzyme activity from actinomycete S2 strain as determined by the production of reducing sugar and $\mathrm{H}_{2} \mathrm{O}_{2}$ was greatly increased by supplementation with ascorbic acid as an electron donor and $\mathrm{Cu}^{2+}$ ions. To the best of our knowledge, this is the first elucidation of LPMO activity from an indigenous Indonesian actinomycete.
\end{abstract}

Keywords: Lignocellulose, LPMO, actinomycete, reducing sugar, Streptomyces avermitilis

\section{INTRODUCTION}

Lignocellulose is a major component of the cell wall of plants and is therefore very abundant on the earth. It consists of three main polymers, namely lignin (10-25\%), hemicellulose $(20-35 \%)$, and cellulose $(35-50 \%)$ (Pradeep et al., 2013). Cellulose, the main component of lignocellulose, is a homogeneous linear polymer of glucosyl units with $\beta(1 \rightarrow 4)$ bonds forming microfibrils in crystalline and amorphous structures. Owing to its particular structure, it is resistant to many lignocellulosedegrading hydrolytic enzymes that are blocked from reaching their substrate (Horn et al., 2012).

Lytic polysaccharide monooxygenase (LPMO) is an enzyme that can break down crystalline polysaccharides, components in cellulose that are not otherwise easily accessible to lignocellulose-degrading hydrolytic enzymes such as cellulase and xylanase. Hence, LPMO enzyme can be used in the pre-treatment process of lignocellulosic waste at an early stage of biodegradation. 
LPMO acts by oxidative cleavage between $\beta(1 \rightarrow 4)$ glucosyl units in cellulose, hemicellulose, glucan, and cellodextrin by forming oxidized gluco-oligosaccharides. Improved accessibility of lignocellulose-degrading enzymes to their substrates by LPMO is reflected in the release of reducing sugars. For example, LPMO from Myceliophthora thermophila (MtLPMO9A) added to cellulase increases the release of glucose from cellulose (Frommhagen et al., 2015). Besides cellulase, another enzyme that participates in the degradation of lignocellulose is xylanase which breaks down xylan in the production of xylitol, ethanol, and oligosaccharides. Xylanase has important roles in the animal feed industry, pulp processing and paper bleaching (Patel and Savanth, 2015). Therefore, xylanase as one of the lignocellulosedegrading hydrolytic enzymes also serves as an indirect indicator of LPMO activity. In this connection, the production of reducing sugar including xylose and others catalyzed by xylanase and other hydrolytic enzymes is enhanced by LPMO activity.

It is of note that LPMO is copper-dependent enzyme, and its activity requires oxygen as well as an electron donor, such as ascorbic acid, gallic acid, or as the result of cellobiose dehydrogenase activity (Westereng et al., 2013; Isaksen et al., 2014; Frommhagen et al., 2015). Accordingly, MtLPMO9A activity on Avicel medium was reportedly capable of producing both oxidized oligosaccharides and xylo-oligosaccharides when ascorbic acid was supplemented as an electron donor (Frommhagen et al., 2015). The activity of LPMO can also be detected quantitatively based on the production of hydrogen peroxide $\left(\mathrm{H}_{2} \mathrm{O}_{2}\right)$, a by-product of the futile side reaction of LPMO activity when an electron donor is available, but cellulose substrate is not. Additionally, the formation of $\mathrm{H}_{2} \mathrm{O}_{2}$ is directly proportional to the concentration of the LPMO, which itself is dependent on availability of a reductant. In that reaction, ascorbic acid or cellobiose dehydrogenase reduces the LPMO with its copper $(\mathrm{Cu})$ center that activates the oxygen molecule by reducing one electron. The release of $\mathrm{H}_{2} \mathrm{O}_{2}$ can be detected through conversion of Amplex Red to resorufin using horseradish peroxidase (HRP) in a fluorometric assay (Kittl et al., 2012).

This research was aimed at examining LPMO activity of actinomycete $\mathrm{S} 2$ strain based on the increase in xylose as one of reducing sugar and the measurement of $\mathrm{H}_{2} \mathrm{O}_{2}$ production. Xylose production would strongly indicate an increase in the accessibility of xylanase in lignocellulose biodegradation. Therefore, the ability to degrade Avicel (crystalline cellulose) and xylanase activity can serve as an initial step in the screening of actinomycetes for LPMO activity. Actinomycetes are Gram-positive bacteria that have the ability for filamentous growth which facilitates these microbes in the penetration of plant tissues, thus enhancing their efficiency in the degradation of natural biopolymers (Barka et al., 2016). In this study, we used actinomycete $S 2$ strain previously isolated from soil in an oil palm plantation in Jambi, Indonesia. This isolate had the best cellulase (index of 2.6) and xylanase (index of 3.87) activities as compared to other isolates with indices between 1.7 to 2.5 and 0.70 to 3.57 for cellulase and xylanase, respectively (Utarti et al., 2020). We initiated this study on the expectation that actinomycete S2 strain could produce LPMO enzyme that plays a synergistic role in conjunction with lignocellulose-degrading hydrolytic enzymes.

\section{MATERIALS AND METHODS}

\section{Actinomycete isolate and culture medium composition}

Actinomycete S2 strain used in this study was previously isolated from soil in an oil palm plantation in Jambi, Indonesia (Utarti et al., 2020). Screening for avicelase activity was conducted using Avicel medium containing $0.5 \mathrm{~g}$ Avicel, $0.5 \mathrm{~g}$ yeast extract, $0.5 \mathrm{~g}$ bacto peptone, $0.05 \mathrm{~g} \mathrm{MgSO} 4 \cdot 7 \mathrm{H}_{2} \mathrm{O}, 0.05 \mathrm{~g} \mathrm{~K} \mathrm{HPO}_{4} \cdot 3 \mathrm{H}_{2} \mathrm{O}, 0.075 \mathrm{~g}$ $\mathrm{KNO}_{3}, 2 \mathrm{~g}$ agar powder in $100 \mathrm{~mL}$ of distilled water and adjusted to $\mathrm{pH}$ 6.2. Xylanase activity was determined in the same medium of similar composition, but with Avicel substituted by $0.5 \mathrm{~g}$ beechwood xylan. Both xylanase and LPMO production was undertaken in a medium modified from Kholis et al. (2015). The modified medium contained $0.5 \mathrm{~g}$ yeast extract, $0.5 \mathrm{~g}$ bacto peptone, $0.05 \mathrm{~g}$ $\mathrm{MgSO}_{4} \cdot 7 \mathrm{H}_{2} \mathrm{O}, 0.05 \mathrm{~g} \mathrm{~K}_{2} \mathrm{HPO}_{4} \cdot 3 \mathrm{H}_{2} \mathrm{O}, 0.075 \mathrm{~g} \mathrm{KNO}_{3}$, trace element solutions in $100 \mathrm{~mL}$ of distilled water, adjusted to $\mathrm{pH}$ 6.0.

\section{Screening for avicelase and xylanase activities}

Avicelase and xylanase activities were evaluated by inoculating in each case a plug (diameter $8 \mathrm{~mm}$ ) of actinomycete S2 strain on either Avicel or beechwood xylan agar medium. Thereafter, incubation was carried out at temperature of $25-27^{\circ} \mathrm{C}$ for 4 days. The enzymatic index (EI) was determined by Gram's iodine test (Kasana et al., 2008) and calculated as:

$$
E I=\frac{\text { diameter of clearing zone }- \text { diameter of colony }}{\text { diameter of colony }}
$$

\section{Effect of $\mathrm{Cu}^{2+}$ ions and ascorbic acid on xylanase activity}

Characteristics of xylanase activity as an indicator of LPMO were determined by examining the effect of $\mathrm{Cu}^{2+}$ ions and ascorbic acid on xylanase reactions using beechwood xylan as a substrate. Three plugs of actinomycete S2 strain culture were inoculated in $100 \mathrm{~mL}$ of $1 \%(\mathrm{w} / \mathrm{v})$ beechwood xylan medium and incubated on a shaker (110 rpm) at temperature of $25-27^{\circ} \mathrm{C}$ for 4 days. The crude xylanase extract was obtained by centrifuging the culture at $13,680 \times g\left(4^{\circ} \mathrm{C}\right)$ for $20 \mathrm{~min}$. Xylanase activity was conducted by measuring the reducing sugar, which derived from the degradation of beechwood xylan.

Reducing sugar was determined by the DNS method as described by Miller (1959). Briefly, a $0.5 \mathrm{~mL}$ aliquot of crude xylanase extract was added to $0.5 \mathrm{~mL}$ of $1 \%(\mathrm{w} / \mathrm{v})$ beechwood xylan in $100 \mathrm{mM}$ Na-phosphate buffer, $\mathrm{pH}$ 
6.0 , and incubated at room temperature for $15 \mathrm{~min}$. The effect of $\mathrm{Cu}^{2+}$ ions was assayed by adding $\mathrm{CuSO}_{4}$ solutions in final concentrations of $1 \mathrm{mM}, 5 \mathrm{mM}$, and 10 $\mathrm{mM}$, while the electron donor effect was tested by adding ascorbic acid to final concentrations of $0.5-2 \mathrm{mM}$. Both copper and ascorbic acid supplements were added to the enzymatic reactions prior to the incubation step. The reactions were stopped by the addition of $1.5 \mathrm{~mL} 3.5$ dinitro-salicylic acid reagent to the mixture and boiling for $10 \mathrm{~min}$. Optical density of the mixtures was recorded at $540 \mathrm{~nm}$ using a UV/Vis spectrophotometer and read against a standard xylose curve. One unit $(U)$ of xylanase activity was defined as the amount of enzyme that released of $1 \mu \mathrm{mol}$ of reducing sugar from beechwood xylan per minute (He et al., 2014).

\section{Optimization of crude LPMO production based on reducing sugar analysis}

Since the reducing sugar, xylose, is released through the synergistic interaction between LPMO and xylanase (one of the hydrolytic enzymes in the crude LPMO extract), LPMO activity could be determined by taking advantage of this reaction. Accordingly, the release of reducing sugar from Avicel (crystalline cellulose preparation that contains $2 \%$ xylan) (Frommhagen et al., 2015) can serve as an indicator for LPMO activity. Crude LPMO extract on Avicel medium was evaluated over several incubation durations to determine the optimum incubation period for crude LPMO extract production. Three plugs of fresh actinomycete S2 strain were cultivated in $100 \mathrm{~mL}$ of $1 \%$ $(\mathrm{w} / \mathrm{v})$ Avicel medium and incubated with shaking at 110 rpm for up to 10 days at temperature of $25-27^{\circ} \mathrm{C}$. Crude LPMO extract was prepared daily from the same culture as described above. Reducing sugar from the reaction of the crude LPMO extract with $1 \%(\mathrm{w} / \mathrm{v})$ Avicel together with $1 \mathrm{mM}$ ascorbic acid as an electron donor was determined as described above.

\section{Determination of LPMO characteristic activities}

In the production of the crude LPMO extract, 3 plugs of actinomycete S2 strain were inoculated onto $100 \mathrm{~mL}$ of $1 \%(\mathrm{w} / \mathrm{v})$ Avicel media and incubated on a $110 \mathrm{rpm}$ shaker at temperature of $25-27{ }^{\circ} \mathrm{C}$ for the optimal incubation time. The crude LPMO extract that was recovered as described above was used for determination of some characteristics on the enzyme preparation. The traits studied included xylanase and CMCase (carboxymethyl cellulase) activities, reducing sugar production and the effects of the electron donor (ascorbic acid), $\mathrm{Cu}^{2+}$ ions and metal binding. Carboxymethyl cellulose and beechwood xylan were used as the substrates for CMCase and xylanase activities, respectively. Xylanase and CMCase activities of actinomycete S2 strain was used for the initial step for screening the isolate character for LPMO activity. Of note, calibration of xylose and glucose standard curve was applied for determining xylanase and CMCase enzyme activities, respectively. One unit of CMCase activity was defined as the amount of enzyme that released of $1 \mu \mathrm{mol}$ of glucose per-minute (Samira et al., 2011).

In assaying LPMO activity based on reducing-sugar production, Bacillus thuringiensis ATCC 33679 was used as a positive control owing to its three genes encoding LPMO (Zhang et al., 2015). Xylanase from Pichia pastoris $\mathrm{KM} 71 \mathrm{H}$ was the negative control for LPMO activity. This is due to, previous report was succeeded to clone xylanase gene to this corresponding yeast (unpublished result) (Irawan Tan, private communication on August, 2018). Therefore, we could use this yeast to verify the effect of ascorbic acid in stimulating only LPMO activity, and not for the xylanase activity. Moreover, characterization of LPMO as copper-dependent enzyme was examined by adding $0.2 \mathrm{mM} \mathrm{Cu}^{2+}$ ions and/or $1 \mathrm{mM}$ ascorbic acid to the LPMO enzyme reaction. In addition, metal binding activity was tested by supplementing 10 $\mathrm{mM}$ of EDTA to the enzyme reaction (He et al., 2014). The DNS method was applied in all reducing sugar production analysis and $1 \%(\mathrm{w} / \mathrm{v})$ Avicel was used as the substrate.

\section{Assay of LPMO activity based on $\mathrm{H}_{2} \mathrm{O}_{2}$ production}

LPMO activity was followed up by testing $\mathrm{H}_{2} \mathrm{O}_{2}$ production using the Amplex Red fluorometric assay, with the crude enzyme preparation of $P$. pastoris $\mathrm{KM} 71 \mathrm{H}$ and Escherichia coli serving as negative controls. The enzyme assays were started by mixing $20 \mu \mathrm{L}$ of the crude LPMO extract/controls with $180 \mu \mathrm{L}$ of assay solution containing $100 \mathrm{mM}$ sodium phosphate buffer $\mathrm{pH} 6.0,30 \mu \mathrm{M}$ ascorbic acid, $50 \mu \mathrm{M}$ Amplex Red (Sigma) and $7.14 \mathrm{U} / \mathrm{mL}$ horseradish peroxidase (Sigma) in a black 96-well plates (total assay volume of $200 \mu \mathrm{L}$ ). All the solutions were mixed and incubated at temperature of $25-27^{\circ} \mathrm{C}$ for 15 $\min$ in the dark condition. Fluorescence was then measured based on resorufin production using excitation and emission wavelengths of $569 \mathrm{~nm}$ and $585 \mathrm{~nm}$, respectively, of the fluorescence plate reader (BMG Lab Tech, USA). A linear relation between fluorescence and $\mathrm{H}_{2} \mathrm{O}_{2}$ concentrations in the range of $0.1-5 \mu \mathrm{M}$ of $\mathrm{H}_{2} \mathrm{O}_{2}$ was constructed for standard calibration. One unit of LPMO activity was defined as the equivalent to the release of 1 $\mu \mathrm{mol}$ of $\mathrm{H}_{2} \mathrm{O}_{2}$ per-minute (Kittl et al., 2012).

\section{Molecular identification of actinomycete S2 strain}

The genomic DNA of the actinomycete S2 strain was extracted following a standard protocol for actinomycete genomic DNA preparations using the Genomic DNA Mini Kit (Geneaid). The 16S rRNA gene was amplified by polymerase chain reaction (PCR) $\left(94^{\circ} \mathrm{C}\right.$ for $4 \mathrm{~min}, 30$ cycles consisting of $94^{\circ} \mathrm{C}$ for $45 \mathrm{sec}, 55^{\circ} \mathrm{C}$ for $60 \mathrm{sec}, 72$ ${ }^{\circ} \mathrm{C}$ for $70 \mathrm{sec}$ followed by a terminal incubation at $72{ }^{\circ} \mathrm{C}$ for $7 \mathrm{~min}$ ) using 63f (5'-CAG GCC TAA CAC ATG CAA GTC-3') and 1387r (5'-GGG CGG WGT GTA CAA GGC$\left.3^{\prime}\right)$ primers (Marchesi et al. 1998). The 16S rRNA gene sequences of the strains were then searched for homology with sequences in the National Center Biotechnology Information (NCBI) public database using 
nucleotide blast (BLASTn) tool (http://www.ncbi.nlm.nih.gov/). Subsequently, the raw sequencing data were trimmed and assembled using ChromasPro program version 1.5. Phylogenetic and molecular evolutionary analyses were conducted using MEGA version 7 and the phylogenetic tree was constructed using the Neighbor-Joining method with a $1000 \times$ replication bootstrap.

\section{RESULTS AND DISCUSSION}

\section{Actinomycete S2 strain exhibits avicelase and xylanase activities}

In the initial analysis, we showed that actinomycete S2 strain displayed avicelase and xylanase enzyme properties with enzyme activity indices of 2.67 and 3.87 , respectively (Figure 1 ). The results indicated that this actinomycete strain could utilize Avicel as a carbon source for its growth and LPMO activity was established by the ability of the enzyme to degrade Avicel (Agger et al., 2014; Frommhagen et al., 2015). In addition, the observed activity of xylanase, as one of the hydrolytic enzymes in lignocellulose biodegradation, could also be used as an indicator of LPMO activity assay based on the release of reducing sugars as a reaction product.

\section{Effect of $\mathrm{Cu}^{2+}$ ions and ascorbic acid on xylanase activity}

Xylanase activity of actinomycete S2 strain was further investigated using beechwood xylan as the substrate. We showed that actinomycete S2 strain xylanase activity of $0.549 \pm 0.079 \mathrm{U} / \mathrm{mL}$ decreased by up to $73 \%(0.150 \pm$ $0.024 \mathrm{U} / \mathrm{mL}), 84 \%(0.089 \pm 0.013 \mathrm{U} / \mathrm{mL})$ and $93 \%(0.0380$ $\pm 0.12 \mathrm{U} / \mathrm{mL}$ ) following $\mathrm{Cu}^{2+}$ supplementation of $1 \mathrm{mM}, 5$ $\mathrm{mM}$ and $10 \mathrm{mM} \mathrm{Cu}^{2+}$, respectively. On the other hand, xylanase activity increased up to nine fold, from $0.343 \pm$ $0.048 \mathrm{U} / \mathrm{mL}$ to $3.315 \pm 0.189 \mathrm{U} / \mathrm{mL}$ in the presence of 1.5 $\mathrm{mM}$ ascorbic acid (Figure 2). We surmise that the increase of xylanase activity of the actinomycete in the presence of ascorbic acid was due to its role as an electron donor for the LPMO reaction. Consistent with our findings, previous research has reported that the glycoside hydrolase family 61 (GH61) of Thermoascus aurantiacus (TaGH61) increased the conversion of microcrystalline cellulose to oxidized cello-oligomers in C1 when gallic acid, another electron donor, was present in the reaction mixture. This particular enzyme is classified as polysaccharide monooxygenase (Phillips et al., 2011; Dimarogona et al., 2012). Additionally, an LPMO from Neurospora crassa (NcLPMO09C) has been reported to carry out a similar oxidative reaction with xyloglucan. Structural similarity between $(1 \rightarrow 4)-\beta-D-x y l a n$ and $(1 \rightarrow 4)-\beta-D$-glucan may indicate that LPMO is involved in xylan degradation (Agger et al., 2014). On the contrary, the xylanase activity of actinomycete S2 strain declined after ascorbic acid supplementation was increased to $2 \mathrm{mM}$. This was presumably due to the higher concentration of ascorbic acid impacting not only
LPMO activity directly, but also influencing its synergistic interaction with xylanase activity at that concentration.

\section{Duration for optimal production of Actinomycete S2 strain crude LPMO}

Microbes produce various enzymes in response to the presence of substrate in their growth media. The growth of actinomycete S2 strain on Avicel medium apparently stimulated the biosynthesis of crystalline-cellulosedegrading enzymes due to cellulose being the only source of carbon available in the medium for its growth. LPMO production was maximal after incubation for six days, with the release of $276.278 \pm 14.404 \mu \mathrm{g} / \mathrm{mL}$ xylose as one of reducing sugar in Avicel substrate and in the presence of ascorbic acid (Figure 3). The LPMO activity was shown to increase three-fold by when ascorbic acid was present in the enzymatic reaction. While Bacillus choshinensis SP3, a mutant developed from the transformation of the sgLPMO10F gene of Streptomyces griseus could produce LPMO after $24 \mathrm{~h}$ of cultivation (Nakagawa et al., 2015). The actinomycete S2 strain used in this study required more time for enzyme production.
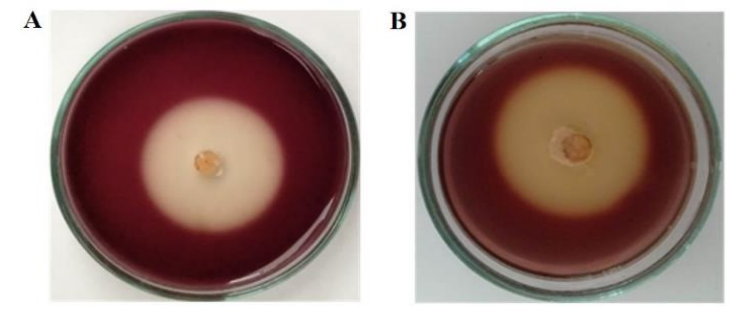

Figure 1: The Avicelase (A) and xylanase (B) activities of actinomycete $\mathrm{S} 2$ strain on Avicel and xylan media $\mathrm{pH}$ 6.0, respectively. Incubation at room temperature for four days was conducted prior to be observed. All figures are representative from triplicates experiments.
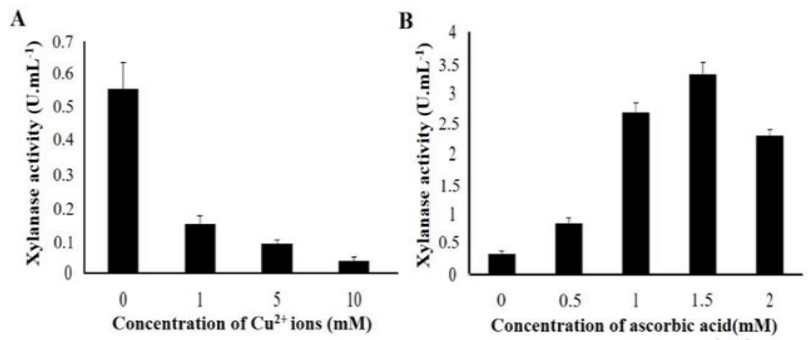

Figure 2: Effect of $\mathrm{Cu}^{2+}$ ions (A) and ascorbic acid (B) on xylanase activity of actinomycete $\mathrm{S} 2$ strain in beechwood xylan growth medium after cultured for 4 days at room temperature. Enzyme activity was determined using beechwood xylan as a substrate in Na-phosphate buffer, $\mathrm{pH}$ 6.0, and incubated at room temperature for 15 minutes. Results were represented from three independent experiments. 


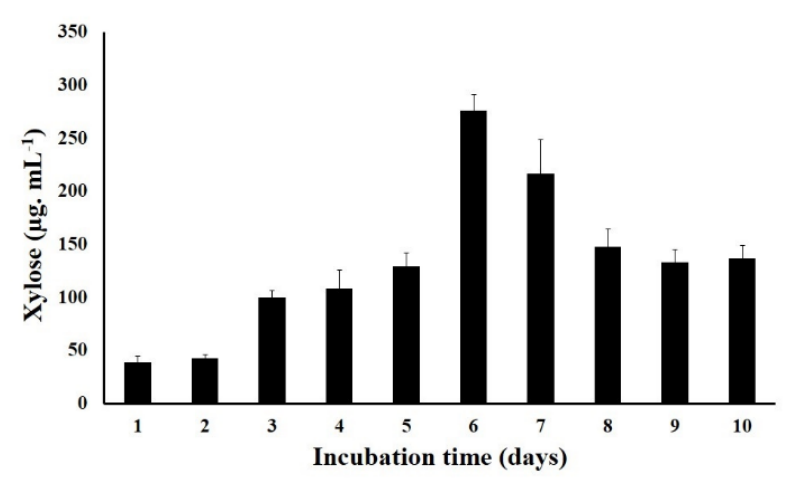

Figure 3: Effect of incubation time on LPMO production from actinomycete S2 strain. The LPMO activity was determined based on reducing sugar production. The LPMO activity assay was carried out in $1 \%(\mathrm{w} / \mathrm{v})$ Avicel as for enzymatic substrate and in the presence of $1 \mathrm{mM}$ ascorbic acid. Data are means and representative from triplicate experiments.

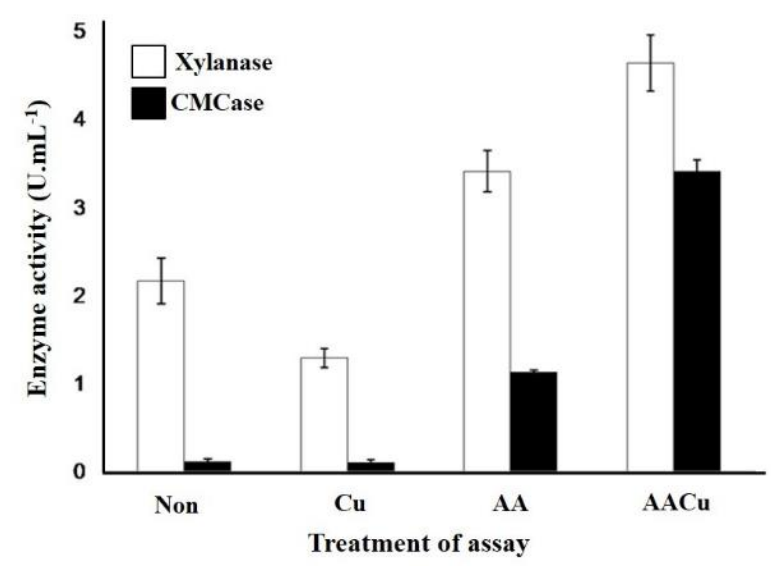

Figure 4: Comparison of crude extract xylanase and CMCase activity of actinomycete S2 strain on $1 \%(\mathrm{w} / \mathrm{v})$ beechwood xylan and CMC as for enzymatic substrate, respectively, following the addition of $\mathrm{Cu}^{2+}$ ions and ascorbic acid. These crude enzymes were produces in $1 \%$ (w/v) Avicel growth medium. Non= without treatment; $\mathrm{Cu}=$ with $\mathrm{Cu}^{2+}$ ions; $\mathrm{AA}=$ with ascorbic acid; $\mathrm{AACu}=$ with ascorbic acid and $\mathrm{Cu}^{2+}$ ions. Data are means and representative from three independent experiments.

\section{LPMO activity of actinomycete $\mathbf{S 2}$ strain determined by reducing-sugar production}

The fact that xylanase activity increased in the presence of ascorbic acid provided a strong indicator that actinomycete S2 strain had LPMO activity. Frommhagen et al. (2015) had earlier reported that the release of glucose produced by enzymatic reaction of cellulase was increased in the presence of LPMO from $M$. thermophila (MtLPMO9A). Interestingly, we found that xylanase and cellulase activities of actinomycete $\mathrm{S} 2$ strain produced on $1 \%(w / v)$ Avicel medium increased after the addition of ascorbic acid and the combination of ascorbic acid and $\mathrm{Cu}^{2+}$ ions in their substrate. With the addition to ascorbic acid, xylanase activity of actinomycete S2 strain was 3.41 $\pm 0.23 \mathrm{U} / \mathrm{mL}$ and that of CMCase was $1.17 \pm 0.02 \mathrm{U} / \mathrm{mL}$. The combination of ascorbic acid and $\mathrm{Cu}^{2+}$ ions resulted in activities of $4.64 \pm 0.32 \mathrm{U} / \mathrm{mL}$ and $3.41 \pm 0.13 \mathrm{U} / \mathrm{mL}$ for xylanase and CMCase activities, respectively. However, the addition of $\mathrm{Cu}^{2+}$ ions alone decreased the activity of xylanase and CMCase to $1.29 \pm 0.11 \mathrm{U} / \mathrm{mL}$ and $0.1 \pm$ $0.02 \mathrm{U} / \mathrm{mL}$, respectively (Figure 4).

Additional assays using Avicel as enzymatic substrate were conducted to elucidate further the effect of copper and ascorbic acid on actinomycete S2 strain enzyme activity. Since Avicel contained $2 \%$ xylan, it would be possible to observe actinomycete $S 2$ strain xylanase activity in Avicel substrate to examine the action of synergistic agents on the activity of the LPMO in crude extract enzyme (Frommhagen et al., 2015). In this investigation, crude extract enzymes from $B$. thuringiensis ATCC 33679 and $P$. pastoris $\mathrm{KM} 71 \mathrm{H}$ were used as controls. Our results indicated that xylose was released from the activity of crude extract enzyme of $B$. thuringiensis ATTC 33679 and actinomycete S2 strain at a basal level of $175.01 \pm 7.20 \mu \mathrm{g} / \mathrm{mL}$ and $255.03 \pm 4.30$ $\mu \mathrm{g} / \mathrm{mL}$, respectively. Intriguingly, the xylose increased by 7 -fold to $1150 \pm 8.82 \mu \mathrm{g} / \mathrm{mL}$ for $B$. thuringiensis ATCC 33679 and 3 -fold to $782.5 \pm 26.30 \mu \mathrm{g} / \mathrm{mL}$ for actinomycete S2 strain when ascorbic acid was present in the Avicel reaction mixture (Figure 5 ). In contrast, xylose released from the xylanase activity of $P$. pastoris $\mathrm{KM} 71 \mathrm{H}$ decreased up to $40 \%$, from $1005.56 \pm 78.76 \mu \mathrm{g} / \mathrm{mL}$ to $605.57 \pm 25.46 \mu \mathrm{g} / \mathrm{mL}$ when ascorbic acid was added in the Avicel. Moreover, a combination of $1 \mathrm{mM}$ ascorbic acid and $0.2 \mathrm{mM} \mathrm{Cu}^{2+}$ ions increased xylose produced by B. thuringiensis ATCC 33679 by 8-fold to $1435 \pm 68.61$ $\mu \mathrm{g} / \mathrm{mL}$ and 5 -fold to $1290 \pm 75.62 \mu \mathrm{g} / \mathrm{mL}$ for actinomycete S2 strain, respectively. However, the same treatment decreased the xylose from xylanase activity of $P$. pastoris $\mathrm{KM} 71 \mathrm{H}$ by $59 \%(416.67 \pm 33.33 \mu \mathrm{g} / \mathrm{mL})$ (Figure 5 ). It is noteworthy that synergistic reactions play an important role in the biodegradation of lignocellulose. In addition to the hydrolytic enzymes that degrade cellulose or hemicellulose, LPMO that has the ability to oxidize crystalline cellulose especially if an electron donor is present in an enzymatic reaction (Andlar et al., 2018). LPMO activity is specific not only to crystalline cellulose, but also to amorphous cellulose, hemicellulose, chitin and other polysaccharides (Agger et al., 2014). In general, biomass degrading bacteria have only one or two LPMOencoding genes, but Streptomyces coelicolor is reported as having seven genes encoding LPMO while $S$. griseus has six LPMO genes (Nakagawa et al., 2015). The finding that ascorbic acid as an electron donor increased the production of reducing sugars and hydrolytic enzyme activity (CMCase and xylanase) were good indicators that actinomycete S2 strain produced LPMO (Figure 4). We also showed that the enzyme activity and reducing sugar product from actinomycete S2 strain was increased in presence of ascorbic acid and $\mathrm{Cu}^{2+}$ ions in combination. This suggests that LPMO was copper-dependent needed 


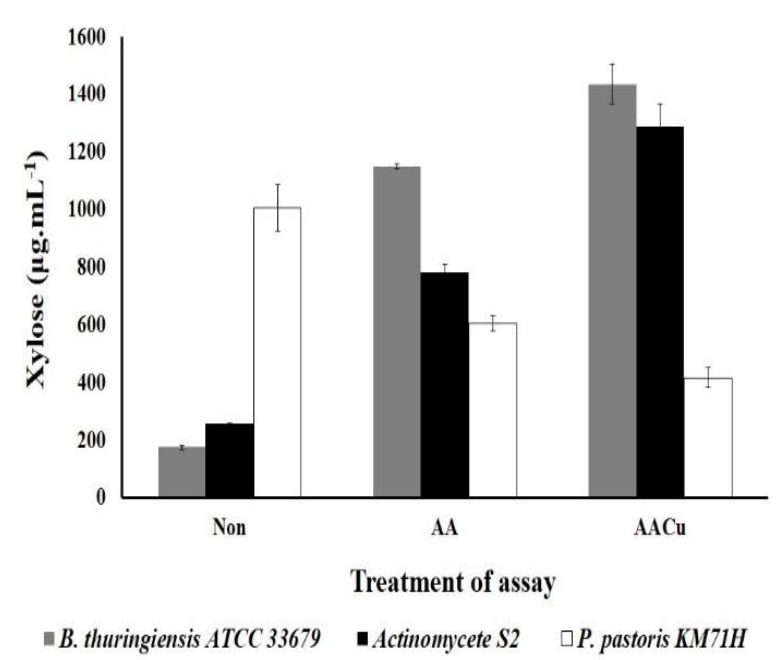

Figure 5: Effect of ascorbic acid and $\mathrm{Cu}^{2+}$ ions on LPMO crude extract of $B$. thuringiensis ATCC 33679, actinomycete $\mathrm{S} 2$ strain and $P$. pastoris $\mathrm{KM} 71 \mathrm{H}$ based on reducing sugar production on Avicel $1 \%$ following the addition of $\mathrm{Cu}^{2+}$ ions and ascorbic acid. Non = normal assay without $\mathrm{Cu}^{2+}$ ions and ascorbic acid; $\mathrm{AA}=$ with ascorbic acid; $\mathrm{AACu}=\mathrm{Cu}^{2+}$ ions and ascorbic acid addition. Results are means and representative from three independent experiments.

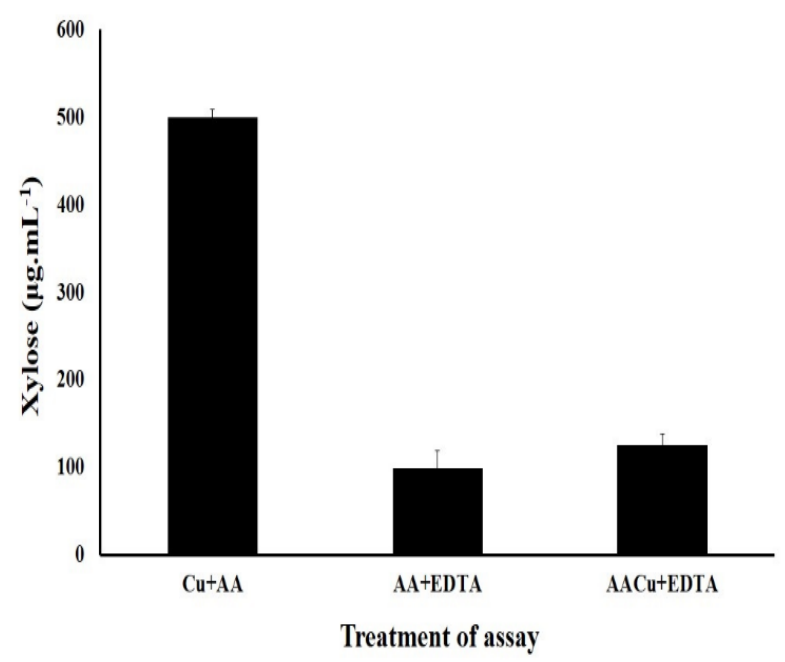

Figure 6: Metal-binding assay of actinomycete S2 strain LPMO activity on $1 \%$ Avicel based on reducing sugar production. $\mathrm{Cu}+\mathrm{AA}=$ addition of $\mathrm{Cu}^{2+}$ ions and ascorbic acid; $E D T A=$ addition of ascorbic acid and EDTA; $\mathrm{CuAA}+\mathrm{EDTA}=$ addition of ascorbic acid, EDTA and $\mathrm{Cu}^{2+}$ ions. Data are means and representative from three independent experiments.

a confirmatory metal-binding test. The decrease in xylanase activity with the addition of $\mathrm{Cu}^{2+}$ ions, in the absence of ascorbic acid as shown in Figure 1, might also point to copper as one of the inhibitors for xylanase activity of actinomycete S2 strain.

The dependence of LPMO activity on copper can be demonstrated by the addition of EDTA (a cation-chelating agent) in the enzymatic reaction (Figure 6). The results showed that $10 \mathrm{mM}$ EDTA decreased xylose production of LPMO of actinomycete S2 strain by $81 \%$, from 500.28 $\pm 8.53 \mu \mathrm{g} / \mathrm{mL}$ to $98.61 \pm 19.73 \mu \mathrm{g} / \mathrm{mL}$. However, when $\mathrm{Cu}^{2+}$ ions were added to the enzymatic reaction, there was a recovery in the production of xylose by $27 \%$, with an increase to $125.56 \pm 13.07 \mu \mathrm{g} / \mathrm{mL}$ (Figure 6). Our results are, therefore, consistent with previous findings that the glycoside hydrolase activity of Phanerochaete chrysosporium (PcGH61D), produced by oxidizing cellooligosaccharides following the addition of ascorbic acid, was inhibited by the addition of EDTA, but a recovery ensued following the addition of copper and manganese (Westereng et al., 2011). Indeed, Nakagawa et al. (2015) and Kracher et al. (2016) note that the active site of LPMO contains two histidines which bind to copper atom. Thus, $\mathrm{Cu}^{2+}$ ions play a critical role in the oxidation process, where the oxygen activation reaction at this active site requires an electron donor.

\section{Actinomycete $\mathrm{S} 2$ strain LPMO activity based on $\mathrm{H}_{2} \mathrm{O}_{2}$ production}

In the absence of cellulose as substrate, LPMO activity can also be detected quantitatively based on its byproduct, $\mathrm{H}_{2} \mathrm{O}_{2}$ (Kittl et al., 2012). Here, we further investigated the LPMO actinomycete S2 strain characteristics in terms of $\mathrm{H}_{2} \mathrm{O}_{2}$ production (Table 1). Using the Amplex Red Fluorimetric assay to quantify $\mathrm{H}_{2} \mathrm{O}_{2}$ production, the crude enzyme from $B$. thuringiensis ATCC 33679 had LPMO activity of $0.029 \pm 0.004 \mathrm{U} / \mathrm{mL}$, while LPMO activity of actinomycete S2 strain was 0.019 $\pm 0.001 \mathrm{U} / \mathrm{mL}$. LPMO activity from the negative controls $P$. pastoris $\mathrm{KM} 71 \mathrm{H}$ and $E$. coli was not detected. However, LPMO activity of actinomycete S2 strain was comparatively lower than that reported for Neurospora crassa $(4.90 \mathrm{U} / \mathrm{mL}$ ) (Kittl et al., 2012). Nonetheless, our results confirmed LPMO enzyme in our sample through $\mathrm{H}_{2} \mathrm{O}_{2}$ production in addition to reducing-sugar production.

\section{Identification of actinomycete S2 strain as Streptomyces sp.}

Gene amplification of actinomycete $\mathrm{S} 2$ strain by PCR with $63 \mathrm{f}$ and $1387 \mathrm{r}$ primers produced DNA fragments of around 1300 bp (Gene Bank deposit number MK050007.1). BLASTn analysis of the 16S rRNA gene sequence of actinomycete S2 strain showed $99 \%$ similarity to the 16S rRNA gene sequence of Streptomyces avermitilis EAAG80 strain (Table 2). Actinomycete $S 2$ strain also has genetic proximity to $S$. yokosukanensis strain EAAG75, S. cellostaticus strain CSSP188, and S. griseochromogenes strain NBRC 13413 (Figure 7). It is noteworthy that $S$. griseochromogenes ATCC 14511 also possesses an LPMO-encoding gene (Lijuan et al., 2017). 
Malays. J. Microbiol. Vol 17(1) 2021, pp. 60-68

DOI: http://dx.doi.org/10.21161/mjm.200869

Table 1: The LPMO activity of actinomycete $\mathrm{S} 2$ strain based on $\mathrm{H}_{2} \mathrm{O}_{2}$ production. LPMO activity from $B$. thuringiensis ATCC 33679 utilized as positive control, while both $P$. pastoris $\mathrm{KM} 71 \mathrm{H}$ and $E$. coli were used as negative controls. One unit LPMO activity is defined as the equivalent value of the release of $1 \mu \mathrm{mol}$ of $\mathrm{H}_{2} \mathrm{O}_{2}$ per-minute. Data are means and representative from three independent experiments.

\begin{tabular}{lcccc}
\hline Isolates & \multicolumn{2}{c}{$\mathrm{H}_{2} \mathrm{O}_{2}$ production $(\mu \mathrm{mol} / \mathrm{L} / \mathrm{min})$} & $\begin{array}{c}\text { LPMO activity } \\
(\mathrm{U} / \mathrm{mL})^{* *}\end{array}$ \\
\cline { 2 - 4 } & With ascorbic acid & No ascorbic acid & Final $\mathrm{H}_{2} \mathrm{O}_{2}{ }^{*}$ & $0.029 \pm 0.004$ \\
\hline B. thuringiensis ATCC 33679 & $0.0135 \pm 0.0008$ & 0.0077 & $0.0058 \pm 0.0008$ & 0.008 \\
Actinomycete S2 strain & $0.0121 \pm 0.0002$ & 0.0081 & $0.0039 \pm 0.0002$ & $0.019 \pm 0.001$ \\
P. pastoris KM71H & $0.0033 \pm 0.00$ & 0.0033 & 0.000 & 0.000 \\
E. coli & $0.0007 \pm 0.00$ & 0.0007 & 0.000 & 0.000 \\
\hline
\end{tabular}

*Final $\mathrm{H}_{2} \mathrm{O}_{2}$ obtained by subtracting mol of $\mathrm{H}_{2} \mathrm{O}_{2}$ production with ascorbic acid and no ascorbic acid treatment.

${ }^{* *} \mathrm{LPMO}$ activity $(\mathrm{U} / \mathrm{mL})$ obtained by converting final mol of $\mathrm{H}_{2} \mathrm{O}_{2}$ production of each sample from reaction of $200 \mu \mathrm{L}$ (total assay volume) to $\mathrm{mL}$ volume (for $\mathrm{U} / \mathrm{mL}$ ), in detail each of $\mathrm{H}_{2} \mathrm{O}_{2}$ final production is multiplied with 1000 (converting to $\mathrm{mL}$ ), then dividing with 200 ( $\mu \mathrm{L}$ ); Ascorbic acid used for an electron donor; B. thuringiensis ATCC 33679 used for positive control of LPMO activity (contained LPMO genes); $P$. pastoris $\mathrm{KM} 71 \mathrm{H}$ used for comparison treatment which have xylanase gene; $E$. coli used for comparison treatment which have no direct relationship with LPMO/xylanase. Each assay was conducted in $200 \mu \mathrm{L}$ volume.

Table 2: The alignment gene of $16 \mathrm{~S}$ rRNA sequence between actinomycete $\mathrm{S} 2$ strain and other species based on sequence data in NCBI (BLASTn).

\begin{tabular}{|c|c|c|c|c|}
\hline Relative species & $\begin{array}{c}\text { Query cover } \\
(\%)\end{array}$ & E value & $\begin{array}{c}\text { Identity } \\
(\%)\end{array}$ & Accession number \\
\hline Streptomyces avermitilis strain EAAG80 & 100 & 0.0 & 99 & KF562159.1 \\
\hline Streptomyces yokosukanensis strain EAAG75 & 100 & 0.0 & 99 & KF032543.1 \\
\hline Streptomyces cellostaticus strain CSSP188 & 100 & 0.0 & 99 & NR_043339.1 \\
\hline Streptomyces griseochromogenes strain NBRC 13413 & 100 & 0.0 & 99 & NR_112396.1 \\
\hline
\end{tabular}

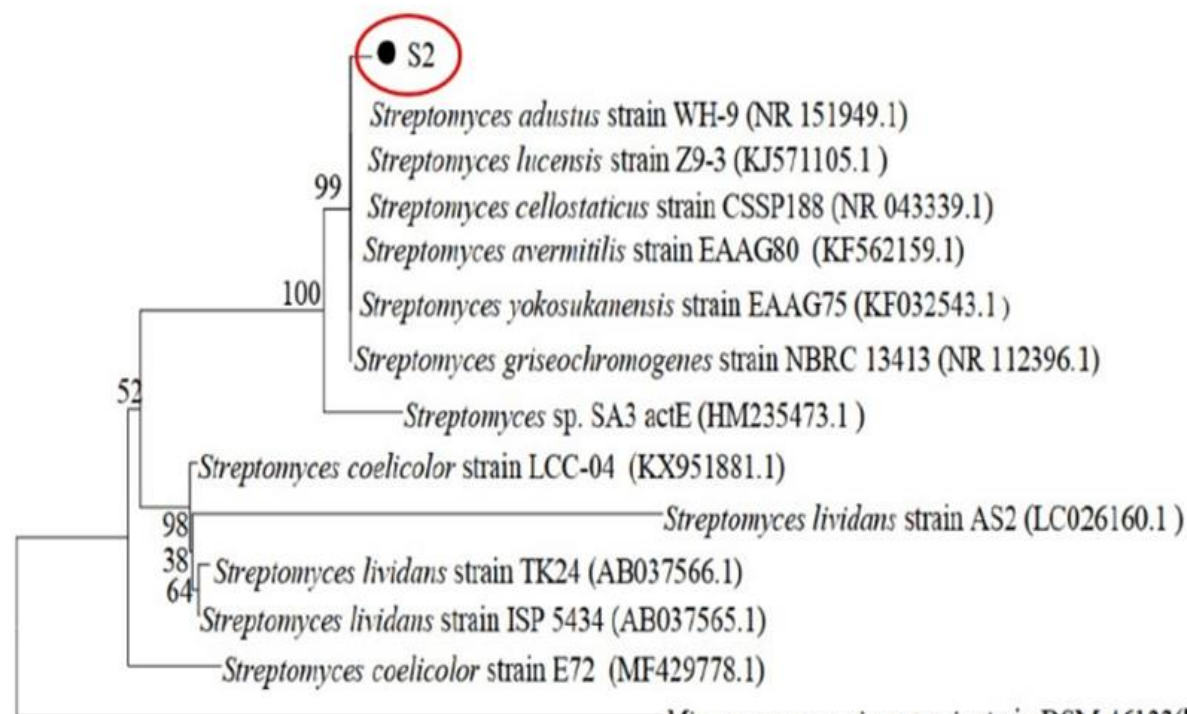

Micromonospora inyonensis strain DSM 46123(NR 044893.1)

0.01

Figure 7: Phylogenetic tree (dendrogram) of actinomycete S2 strain 16S rRNA gene sequences using the neighborjoining method. Bootstrap test $=1000$ replicates. The evolutionary distances were computed using the Tamura model. Analysis was conducted using Mega 7 software. 


\section{CONCLUSION}

Actinomycete S2 strain is capable of producing LPMO enzyme which can be detected based on the release of reducing-sugar and the formation of hydrogen peroxide. This reaction being enhanced by the addition of ascorbic acid as an electron donor and $\mathrm{Cu}^{2+}$ ions to the enzymatic reaction. On the basis of the 16S rRNA gene analysis, actinomycete $S 2$ strain bears a close relationship to $S$. avermitilis strain EAAG80, with about $99 \%$ similarity. As far as we are able to ascertain, this is the first elucidation of LPMO activity from an indigenous Indonesian actinomycete.

\section{ACKNOWLEDGEMENTS}

We gratefully thank to the Ministry of Research, Technology and Higher Education of Indonesia for all supports with the letter decree No. 180927/A4.2/KP/2014 through the Postgraduate Educational Scholarship. Part of the research was funded by ABS Fund CRC 990 Research Group B02, 2017 awarded to Anja Meryandini.

\section{REFERENCES}

Agger, J. W., Isaksen, T., Varnal, A., Vidal-Melgosa, S., Willats, W. G. T., Ludwig, R., Horn, S. J., Eijsink, V. G. H. and Westereng, B. (2014). Discovery of LPMO activity on hemicelluloses shows the importance of oxidative processes in plant cell wall degradation. PNAS 111(17), 6287-6292.

Andlar, M., Rezic, T., Mardetko, N., Kracher, D., Ludwig, R. and Santek, B. (2018). Lignocellulose degradation: An overview of fungi and fungal enzymes involved in lignocelluloses degradation. Engineering in Life Sciences 18(11), 768-778.

Barka, E. A., Vatsa, P., Sanchez, L., Gaveau-Vallant, N., Jacquard, C., Klenk, H. P., Clement, C., Ouhdouch, Y. and van Wezel, G. P. (2016). Taxonomy, physiology, and natural product of actinobacteria. Microbiology and Molecular Biology Reviews 80(1), 1-44.

Dimarogona, M., Topakas, E. and Christakopaulas, P. (2012). Cellulose degradation by oxidative enzymes. Computational and Structural Biotechnology Journal 2(3), 1-8.

Frommhagen, M., Sforza, S., Westphal, A. H., Visser, J., Hinzz, S. W. A., Koetsier, M. J., van Berkel, W. J. H., Gruppen, H. and Kabel, M. A. (2015). Discovery of the combined oxidative cleavage of plant xylan and cellulose by a new fungal polysaccharide monooxygenase. Biotechnology for Biofuels 8(101), 112.

He, J., Su, L., Sun, X., Fu, J., Chen, J. and Wu, J. (2014). A novel xylanase from Streptomyces sp. FA1: Purification, characterization, identification and heterologous expression. Biotechnology and Bioprocess Engineering 19(1), 8-17.

Horn, S. J., Vaaje-Kolstad, G., Westereng, B. and Eijsink, V. G. H. (2012). Novel enzymes for the degradation of cellulose. Biotechnology for Biofuels 5(1), 1-12.

Isaksen, T., Westereng, B., Aachmann, F. L., Agger, J. W., Kracher, D., Kittl, R., Ludwig, R., Haaltrich, D., Eijsink, V. G. H. and Horn, S. J. (2014). A C4oxidizing lytic polysaccharide monooxygenase cleaving both cellulose and cello-oligosaccharide. Journal of Biological Chemistry 289(5), 2632-2642.

Kasana, R. C., Salwan, R., Dhar, H., Dutt, S. and Gulati, A. (2008). A rapid and easy method for the detection of microbial cellulases on agar plates using Gram's iodine. Current Microbiology 57(5), 503-507.

Kholis, M. N., Yopi, and Meryandini, A. (2015). Xylooligosaccharide production from tobacco stalk xylan using xylanase Streptomyces sp. BO 3.2. Makara Journal of Science 19(2), 49-54.

Kittl, R., Kracher, D., Burgstaller, D., Haltrich, D. and Ludwig, R. (2012). Production of four Neurospora crassa lytic polysaccharide monooxygenases in Pichia pastoris monitored by a fluorimetric assay. Biotechnology for Biofuels 5(1), 1-13.

Kracher, D., Scheiblbrandner, S., Felice, A. K. G., BresImayr, E., Preims, M., Ludwicka, K., Haltrich, D., Eijsink, V. G. H. and Ludwig, R. (2016). Extracellular electron transfer system fuel cellulose oxidative degradation. Science 352(6289), 1-4.

Lijuan, W., Chen, G. and Feng, G. (2017). Complete genome sequence of Streptomyces griseochromogenes ATCC 14511, a producer of nucleoside compounds and diverse secondary metabolites. Journal of Biotecnology 249, 16-19.

Marchesi, J. R., Sato, T., Weightman, A. J., Martin, T. A., Fry, J. C., Hiom, S. J. and Wade, W. G. (1998). Design and evaluation of useful bacterium-specific PCR primers that amplify genes coding for bacterial 16S rRNA. Applied and Environmental Microbiology 64 (6), 795-799.

Miller, G. L. (1959). Use dinitrosalicylic acid reagent for determination of reducing sugar. Analytical Chemistry 31(3), 426-428.

Nakagawa, Y. S., Kudo, M., Loosa, J. S. M., Ishikawa, T., Totani, K., Eijsink, V. G. H. and Vaaje-Kolstad, G. (2015). A small lytic polysaccharide monooxygenase from Streptomyces griseus targeting $\alpha-$ and $\beta$-chitin. FEBS Journal 282(6), 1065-1079.

Patel, S. J. and Savanth, V. D. (2015). Review on fungal xylanases and their applications. International Journal Advance Research 3(3), 311-315.

Phillips, C. M., Beeson, W. T., Cate, J. H. and Marletta, M. A. (2011). Cellobiose dehydrogenase and a copper-dependent polysaccharide monooxygenase potentiate cellulose degradation by Neurospora crassa. ACS Chemical Biology 6(12), 1399-1406.

Pradeep, G. C., Choi, Y. H., Choi, Y. S., Seong, C. N., Cho, S. S., Lee, H. J. and Yoo, J. C. (2013). A novel thermostable cellulase-free xylanase stable in broad range of $\mathrm{pH}$ from Streptomyces sp. CS428. Process Biochemistry 48(8), 1188-1196.

Samira, M., Mohammad, R. and Gholamreza, G. (2011). Carboxymethyl-cellulase and filter-paperase activity of 
Malays. J. Microbiol. Vol 17(1) 2021, pp. 60-68

DOI: http://dx.doi.org/10.21161/mjm.200869

new strain isolated from Persian Gulf. Microbiology Journal 1(1), 8-16.

Utarti, E., Suwanto, A., Suhartono, M. T., and Meryandini, A. (2020). Identification of cellulolytic and xylanolytic indigenous actinomycete. Berkala Sainstek 8(1), 1-5.

Westereng, B., Ishida, T., Vaaje-Kolstad, G., Wu, M., Eijsink, V. G. H., Igarashi, K., Samejima, M., Stahlberg, J., Horn, S. J. and Sandgren, M. (2011). The putative endoglucanase PcGH61D from Phanerochaete chrysosporium is a metal-dependent oxidative enzyme that cleaves cellulose. PlosOne 6(11), e27807.

Westereng, B., Agger, J. W., Horn, S. J., Vaaje-Kolstad, G., Aachmann, F. L., Stenstorm, Y. H. and Eijsink, V. G. H. (2013). Efficient seperation of oxidized cellooligosaccharides generated by cellulose degrading lytic polysaccharide monooxygenase. Journal of Chromatography A 1271(1), 144-152.

Zhang, H., Zhao, Y., Cao, H., Mou, G. and Yin, H. (2015). Expression and characterization of lytic polysaccharide monooxygenase from Bacillus thuringiensis. International Journal of Biological Macromolecules 79, 72-75. 